\title{
Production and evaluation of potassium fertilizers from silicate rock
}

\author{
Wedisson Oliveira Santos ${ }^{1 *}$, Edson Marcio Mattiello ${ }^{1}$, Leonardus Vergutz ${ }^{1}$, and Rodolfo Fagundes Costa ${ }^{1}$ \\ ${ }^{1}$ Department of Soil Science, Universidade Federal de Viçosa (UFV), Av P H Rolfs, Viçosa, Minas Gerais, Brazil, CEP $36570-000$
}

\begin{abstract}
Rising price and limited geographical availability of traditional sources of potassium (K) fertilizers have stimulated a search for alternative $\mathrm{K}$ sources in different parts of the world. We evaluated mineral transformations and agronomic properties of an alternative source of $\mathrm{K}$ produced through thermal and chemical treatment of the verdete rock (VR). Chemical and mineralogical characteristics were evaluated before and after each treatment. Four K sources (verdete rock, $\mathrm{KCl}$, acidified verdete, and calcinated verdete) were applied to a Typic Hapludox at different rates. Eucalyptus and sequentially cropped maize and grass were grown in the treated soils. Verdete rock, which contained glauconite and microcline as $\mathrm{K}$ crystalline minerals, had very low solubility in water and in citric acid. Thermal and chemical treatments increased the concentration of water soluble $\mathrm{K}$ and citric acid soluble $\mathrm{K}$. These treatments also caused crystalline $\mathrm{K}$ minerals to collapse and form sylvite and arcanite. Untreated verdete rock was not suitable as a K source for maize (Zea mays L.) and eucalyptus (Eucaliptus urograndis 1144). Thermal and chemical treatments increased agronomic performance of VR to be similar to $\mathrm{KCl}$. When $\mathrm{K}$ was applied as $\mathrm{K}$-calcined verdete, $82 \%$ of the total $\mathrm{K}$ was recovered in maize and grass cultivations. Less $\mathrm{K}$ was recovered in plant following addition of $\mathrm{K}$-acidified verdete and $\mathrm{KCl}(72 \%$ and $77 \%$, respectively). Potassium recoveries by eucalyptus were about 52,53 , and $60 \%$ of the amount applied of calcined verdete, acidified verdete, and $\mathrm{KCl}$, respectively. Both calcination and thermal treatment increased the $\mathrm{K}$ uptake and dry matter production for all plant species tested to be similar to $\mathrm{KCl}$ suggesting that this silicate rock could be beneficiated to be an effective $\mathrm{K}$ fertilizer.
\end{abstract}

Key words: glauconitic rock / sources of $\mathrm{K} /$ verdete

Accepted May 22, 2016

\section{Introduction}

Potassium $(\mathrm{K})$ is a plant nutrient generally found in low concentrations in tropical soils. Due to the high demand of $\mathrm{K}$ for crop production, this nutrient is required in large amounts as fertilizer. On the other hand, few countries in the world are self-sufficient in the production of $\mathrm{K}$ fertilizers due to the limited natural occurrence of soluble $\mathrm{K}$ minerals such as sylvite $(\mathrm{KCl})$, arcanite $\left(\mathrm{K}_{2} \mathrm{SO}_{4}\right)$, carnallite $\left(\mathrm{KMgCl}_{3} \cdot 6 \mathrm{H}_{2} \mathrm{O}\right)$, and langbeinite $\left[\left(\mathrm{K}_{2} \mathrm{Mg}_{2}\left(\mathrm{SO}_{4}\right)_{3}\right)\right]$. Potassium ore reserves are found mostly in the Northern Hemisphere, specifically in Canada, Russia, Belarus, and Germany. Together, these countries are responsible for approximately $85 \%$ of the $\mathrm{K}$ market worldwide (Lima and Neves, 2012; Ott, 2012).

Potassium fertilizer consumption continues to increase every year, but due to uncertainties about the future market supply of $\mathrm{K}$ fertilizers countries like Brazil, China, and India have directed research to exploitation of domestic sources of $\mathrm{K}$ from silicates ores (Eichler, 1983; Varadachari, 1992; Yadav and Sharma, 1992; Mazumder et al., 1993; Nascimento and Loureiro, 2004; Loureiro et al., 2010; Toledo Piza et al., 2011; Santos et al., 2015). These investigations have shown that there is an abundance of $\mathrm{K}$ minerals, such as micas and feldspars, in common rocks of all of these countries. However, these minerals have very low water solubility and their effectiveness as a fertilizer for plant growth has been questioned (Blum et al., 1989; Coroneos et al., 1995; Ramezanian et al., 2013).

Increasing the water-solubility of $\mathrm{K}$ in these minerals has been investigated previously using chemical and thermal treatments (Eichler, 1983; Nascimento, 2004; Santos et al., 2015).

In Brazil, one of the most abundant $\mathrm{K}$ silicate rock is verdete, a metasedimentary rock formed during the NeoProterozoic era. Glauconite minerals and potassium feldspars are the main K minerals in this rock (Toledo Piza et al., 2011; Santos et al., 2015). The total reserve of this rock in Brazil is unknown, however, the municipality of Cedro do Abaeté is known to have reasonable reserves of verdete (57.4 million tons) (Alecrim, 1982). The potassium concentration in verdete rock varies from 42 to $75 \mathrm{~g} \mathrm{~kg}^{-1}$ (Santos et al., 2015).

Although several studies have investigated the effects of chemical and thermal treatments on potassium silicate rock (Eichler, 1983; Mazumder et al., 1993; Valarelli et al., 1993; Nascimento, 2004; Toledo Piza et al., 2011; Santos et al., 2015), the availability of $\mathrm{K}$ in these products to crops remains unclear.

*Correspondence: W. O. Santos; e-mail: wedosantos@gmail.com 
Our goal is to develop alternative potassium fertilizers by reacting $\mathrm{K}$ rock [verdete rock (VR)] with an acid industrial effluent (AIE), and subjecting the material to thermal processing using $\mathrm{CaCl}_{2}$ as a fluxing agent (FA). The specific aims of this research are to (1) analyze the mineral composition of the products of chemical [Acidified verdete (AV)] and thermal [Calcined verdete (CV)] treatments, (2) measure the availability of $\mathrm{K}$ in these products based on extraction with water and citric acid, and (3) use greenhouse trials to compare the agronomic efficiencies of $\mathrm{AV}$ and $\mathrm{CV}$ to a reference $\mathrm{K}$ fertilizer $(\mathrm{KCl})$ and VR using maize (Zea mays L.), grass (Panicum maximum cv. Mombaça), and eucalyptus (Eucalyptus urograndis).

\section{Material and methods}

\subsection{Rock sampling and preparation}

A representative sample of $10 \mathrm{~kg}$ of verdete rock was collected in Cedro do Abaeté in Minas Gerais State, Brazil. Geologically, verdete rock occurs in the Bambuí formation on the Serra da Saudade in the São Francisco Craton (Valarelli et al., 1993). Prior to chemical and mineralogical analyses, rock samples were ground and passed through a $75-\mu \mathrm{m}$ sieve (200 mesh). Before thermal and chemical treatment, rock was passed through a larger sieve $(150-\mu \mathrm{m}$ sieve, 100 mesh).

\subsection{Acidified Verdete}

In order to produce the acidified verdete, we used an acid industrial effluent (AIE), collected from London \& Scandinavian Metallurgical Brasil S.A (LSM), and located in São João Del Rei, Minas Gerais State, Brazil. This effluent is the by-product of tantalum ( $\mathrm{Ta}$ ) and niobium $(\mathrm{Nb})$ production from pegmatite and uses a three-acid $\left(\mathrm{H}_{2} \mathrm{SO}_{4} / \mathrm{HF} / \mathrm{HCl}\right)$ leaching process. The annual production of AIE is around $22,800 \mathrm{~m}^{3}$, which after alkaline neutralization results in $12,700 \mathrm{Mg}$ of mud (Personal communication from LSM). The AIE had a very low $\mathrm{pH}(\approx 0)$ and concentrations of cations and anions were above those permitted by national legal limits (BRASIL, 2011) for disposal into a receiving watercourse (Table 1 ). The AIE was used to increase verdete reactivity and to potentially produce soluble $\mathrm{K}$ minerals at a low cost by reusing this industrial waste.

For acidified verdete production, $3 \mathrm{~g}$ of ground VR was reacted with $12 \mathrm{~mL}$ of AIE in $50 \mathrm{~mL}$ centrifuge tubes and stirred at $150 \mathrm{rpm}$ on a horizontal shaker table for $72 \mathrm{~h}$. After shaking, the tubes were opened and placed in a water bath at $90 \pm 5^{\circ} \mathrm{C}$ for $4 \mathrm{~h}$ in order to reduce or eliminate excess fluorine. The material was then dried in an air circulation laboratory oven at $105^{\circ} \mathrm{C}$ for $72 \mathrm{~h}$. After cooling, this material was ground in an agate mortar and passed through a 150- $\mu \mathrm{m}$ sieve for standardization and stored in acrylic tubes.

\subsection{Calcined Verdete}

Ground verdete rock and calcium chloride $\left(\mathrm{CaCl}_{2} \cdot 2 \mathrm{H}_{2} \mathrm{O}\right)$ were mixed at a 1:1 ratio. Samples of $4 \mathrm{~g}$ of this mixture were placed in carbon crucibles and calcined in a muffle furnace at $900^{\circ} \mathrm{C}$ for $60 \mathrm{~min}$. The heating ramp was linear with a duration of $45 \mathrm{~min}$. After calcination, the products were crushed in an agate mortar and passed through a sieve with a $150-\mu \mathrm{m}$ mesh. Previous calcination test of verdete using $\mathrm{CaCl}_{2} \cdot 2 \mathrm{H}_{2} \mathrm{O}$ as FA indicated that $900^{\circ} \mathrm{C}$ at $60 \mathrm{~min}$ was the best treatment to solubilize VR in terms of extractable K (Santos et al., 2015). The viability of producing this fertilizer on an industrial scale has not yet been investigated.

\subsection{X-ray diffraction (XRD)}

X-ray diffraction (XRD) analysis of samples before and after each treatment were carried out using a X'Pert Pro MPD Panalytical diffractometer in the 4 to $80^{\circ} 2 \theta$ range with Co-Ko radiation $(\lambda=1.789 \AA)$ at a rate of $0.02^{\circ} 2 \theta \mathrm{s}^{-1}$, operated at $40 \mathrm{kV}$ and $30 \mathrm{~mA}$. Powder mounts were prepared by packing ground $(\leq 0.075 \mathrm{~mm})$ samples into aluminum holders.

\subsection{Greenhouse trials}

The agronomic efficiency of fertilizers was evaluated in a greenhouse pot experiment using two separate cropping systems: grass was grown in rotation with maize and eucalyptus was tested as a single crop. The soil samples were collected from the top layer $(0-30 \mathrm{~cm})$ of a Typic Hapludox in the mu-

Table 1: Chemical characteristics of the acid industrial effluent (AIE) from London \& Scandinavian Metallurgical_Brazil S.A. ${ }^{a}$

\begin{tabular}{|c|c|c|c|c|c|c|c|c|}
\hline $\mathrm{pH}$ & $\begin{array}{l}\mathrm{Ca} \\
/ \mathrm{mg}\end{array}$ & Mg & $\mathbf{K}$ & $\mathrm{Fe}$ & $\mathrm{Zn}$ & $\mathrm{Cu}$ & Mn & Al \\
\hline 0.0 & 46 & 4.7 & 3438 & 13595 & 44 & 57 & 1199 & 897 \\
\hline $\mathrm{Cr}$ & $\mathbf{N i}$ & $\mathrm{Pb}$ & $\mathbf{F}^{-}$ & $\mathrm{SO}_{4}^{2-}$ & $\mathrm{N}-\mathrm{NO}_{3}^{-}$ & $\mathrm{P}-\mathrm{PO}_{4}^{3-}$ & $\mathrm{Cl}^{-}$ & \\
\hline$/ \mathrm{mg} \mathrm{L}^{-1}$ & & & $/ \mathrm{g} \mathrm{L}^{-1}$ & & & & & \\
\hline 59 & 126 & 56 & 109 & 791 & 18 & 19 & 128 & \\
\hline
\end{tabular}

${ }^{\mathrm{a}} \mathrm{Cl}^{-}, \mathrm{F}^{-}, \mathrm{SO}_{4}^{2-}, \mathrm{N}-\mathrm{NO}_{3}^{-}, \mathrm{P}_{-} \mathrm{PO}_{4}^{3-}$ contents were determined by liquid ionic chromatography (DX500, Dionex-Sunnyvale-CA). $\mathrm{Cd}, \mathrm{Ni}, \mathrm{Pb}, \mathrm{Cd}, \mathrm{Cr}$, $\mathrm{Al}, \mathrm{Fe}, \mathrm{Mn}, \mathrm{Cu}, \mathrm{Zn}, \mathrm{Ca}$, and $\mathrm{Mg}$ contents were determined by optic spectroscopy plasma emission (ICP-OES) (PerkinElmer, Optima TM $4300 \mathrm{DV})$. K content was determined by flame emission spectrophotometry (B462-Micronal). 
nicipality of Vicosa, Minas Gerais State, Brazil. Briefly, the soil had low $\mathrm{K}$ concentrations (17 $\mathrm{mg} \mathrm{dm}^{-3}$, Mehlich-1 extractor) and comprised $72 \%$ clay with a $\mathrm{pH}_{\text {water }}$ of $5.6, \mathrm{Ca}^{2+}$ and $\mathrm{Mg}^{2+}$ concentrations of 18.3 and $4.7 \mathrm{mmol}_{\mathrm{c}} \mathrm{dm}^{-3}$, respectively $(\mathrm{KCl} 1 \mathrm{M}$ extractor), and a soil organic $\mathrm{C}$ concentration of $15.5 \mathrm{~g} \mathrm{~kg}^{-1}$ (Walkley and Black, 1934). Samples were airdried and passed through a sieve $(4 \mathrm{~mm})$ for the pot experiments and through a 2-mm screen for chemical and physical analysis. Soil ( 3 and $4 \mathrm{dm}^{3}$ ) was put into the plastic bags and lime $\left(\mathrm{CaCO}_{3}: \mathrm{MgCO}_{3}\right.$ at $\mathrm{Ca} / \mathrm{Mg}$ ratio of $\left.4: 1\right)$ was applied to increase the base saturation to $60 \%$. Soil was wetted to $80 \%$ of the field capacity and maintained at that level for $30 \mathrm{~d}$. After this time, soil was dried, homogenized, and re-analyzed. Basal nutrients N, P, S, Zn, Mn, Fe, Cu, B, and Mo were applied at a rate of $150,300,80,4,3.6,1.5,1.3,0.8$, and $0.15 \mathrm{mg} \mathrm{dm}^{-3}$, respectively. Soil and fertilizers were thoroughly mixed before repotting.

Treatments were arranged in a factorial design $4 \times 3+1$, evaluating four $\mathrm{K}$ sources ( $\mathrm{VR}, \mathrm{AV}, \mathrm{CV}$, and $\mathrm{KCl}$ ) at three rates of $\mathrm{K}\left(50,100\right.$, and $\left.200 \mathrm{mg} \mathrm{dm}^{-3}\right)$. A control without $\mathrm{K}$ application was included. The experiment was a randomized block design with four replications. These treatments were applied to three crops: a maize ${ }^{1 s t}-$ grass $^{2 n d}$ succession and a single eucalyptus cultivation.

Five seeds of maize were planted in pots containing $3 \mathrm{dm}^{3}$ of soil, and two plants grown for $45 \mathrm{~d}$. Roots and shoots were harvested separately and washed with distilled water. The material was dried at $65 \pm 3^{\circ} \mathrm{C}$ until weight stabilization $(\approx 72 \mathrm{~h}$ ), weighed, and milled for chemical analysis. Approximately $300 \mathrm{~cm}^{3}$ of soil were collected for chemical analysis. The remaining soil samples (approximately $2.7 \mathrm{dm}^{3}$ ) were air dried, homogenized, and passed through a sieve with a 4-mm mesh and repotted. Then, grass seeds were sown and cultivated for $60 \mathrm{~d}$ in the same soil samples. Plants were harvested and processed as describe above for maize.

For eucalyptus cultivation, seedlings (clone I 144) were grown in $4 \mathrm{dm}^{3}$ of soil for $90 \mathrm{~d}$. Roots and shoots were harvested separately and washed with distilled water. The material was dried at $65 \pm 3^{\circ} \mathrm{C}$ until weight stabilization $(\approx 72 \mathrm{~h})$, weighed, and milled for chemical analysis. Soil was homogenized and approximately $300 \mathrm{~cm}^{3}$ were collected for chemical analysis.

\subsection{Chemical analysis}

Total, water-soluble and citric acid-soluble $\mathrm{K}$ from VR, AV, and $\mathrm{CV}$, as well as $\mathrm{KCl}$ were measured as described by Alcarde (2009) in accordance with the Brazilian Ministry of Agriculture, Livestock and Food Supply Normative Instruction \#28 (BRASIL, 2007). Citric acid is a non-standard extracting solution for $\mathrm{K}$ fertilizers, but it was used due to the low water solubility of $\mathrm{K}$ in the silicate minerals and citric acid is commonly excreted in high amounts to the rhizosphere of plants. Thus, we presume that it can be a complementary measurement for availability of $\mathrm{K}$ for plant nutrition.

The total $\mathrm{K}$ concentration of fertilizer samples was analyzed using the tri-acid digestion method EPA 3052 (1996). For water-soluble $\mathrm{K}$ analysis, $1.0 \mathrm{~g}$ of fertilizer was placed in an
Erlenmeyer flask with $50 \mathrm{~mL}$ distilled water. Suspensions were then boiled on a hot plate for $10 \mathrm{~min}$. Potassium that was soluble in $2 \%$ citric acid was measured by extracting $0.5 \mathrm{~g}$ of fertilizer with $50 \mathrm{~mL}$ of this solution. Samples were shaken at $150 \mathrm{rpm}$ for $30 \mathrm{~min}$ in a horizontal laboratory shaker. Samples from both extractions were filtered using Whatman Grade $595(4-7 \mu \mathrm{m})$ filter paper. The K concentration in all extracts was determined in triplicate by flame emission spectrophotometry. The relative abundance of water or citric acid-soluble $\mathrm{K}(\%)$ was calculated using the total amount of $\mathrm{K}$ in each fertilizer.

The plant material (maize, grass, and eucalyptus) was digested in an open-vessel-digestion system using a nitricperchloric solution [3:1 (v/v)] (Miller, 1998). Soil samples were analyzed for Mehlich-1 extractable K (Nelson et al., 1953).

For all extracts (fertilizers, plant, and soil), $\mathrm{K}$ concentrations were measured using flame emission spectrophotometry (B462-Micronal).

\subsection{Data and statistical analysis}

The data were initially analyzed using a one-way analysis of variance (ANOVA). The effects of $K$ dose on dry matter, total $\mathrm{K}$ concentration, $\mathrm{K}$ concentration of reference leaves, and soil $\mathrm{K}$ availability, for each $\mathrm{K}$ source, were determined using regression analysis.

Estimated values of $\mathrm{K}$ uptake were calculated through fitted regression models. The recovery of $\mathrm{K}$ was calculated by slope of regression model of $\mathrm{K}$ uptake by plants.

\section{Results}

\subsection{Chemical characterization}

Verdete rock contained $77 \mathrm{~g} \mathrm{~kg}^{-1}$ of $\mathrm{K}$ but only $0.6 \%$ of the total concentration of $\mathrm{K}$ was water-soluble, and only $2.1 \%$ was citric acid-soluble (Table 2). Chemical and thermal treatments increased $\mathrm{K}$ solubility in VR but resulted in a dilution of the total $\mathrm{K}$ content (Table 2). The total concentration of $\mathrm{K}$ was

Table 2: Total, water and citric acid soluble $\mathrm{K}$ content in verdete rock, acidified verdete, calcined verdete, and $\mathrm{KCl}$.

\begin{tabular}{|c|c|c|c|}
\hline \multirow[t]{3}{*}{ Product } & \multirow{3}{*}{$\begin{array}{l}\text { Total K } \\
/ \mathrm{g} \mathrm{kg}^{-1}\end{array}$} & \multirow{2}{*}{$\begin{array}{l}\text { Soluble K } \\
\text { water }\end{array}$} & \multirow[b]{2}{*}{ citric acid } \\
\hline & & & \\
\hline & & $/ \%(w / w)$ & \\
\hline $\begin{array}{l}\text { Verdete } \\
\text { rock }\end{array}$ & $77 \pm 2$ & $0.6 \pm 0.4$ & $2.1 \pm 0.1$ \\
\hline $\begin{array}{l}\text { Acidified } \\
\text { verdete }\end{array}$ & $44 \pm 2$ & $80.6 \pm 3.7$ & $57.3 \pm 2.1$ \\
\hline $\begin{array}{l}\text { Calcined } \\
\text { verdete }\end{array}$ & $36 \pm 1$ & $93.7 \pm 3.0$ & $100.0 \pm 1.3$ \\
\hline $\mathrm{KCl}$ & $521 \pm 1$ & $100.0 \pm 0.1$ & $100.0 \pm 0.0$ \\
\hline
\end{tabular}


44 and $36 \mathrm{~g} \mathrm{~kg}^{-1}$ after chemical and thermal treatments of VR, respectively. The extractability of $\mathrm{K}$ in water was $81 \%$ and $93 \%$ for $\mathrm{AV}$ and $\mathrm{CV}$, respectively. Using citric acid, reactivity increased by $27-$ and 48 -fold, while the $\mathrm{K}$ extractabilities of AV and CV were 57 and $100 \%$, respectively. The extractability of $\mathrm{K}$ from $\mathrm{AV}$ was less in citric acid (57\%) to compared to than in water (81\%) (Table 2).

\subsection{Mineralogical characterization}

The diffractogram for $\mathrm{VR}$ revealed the presence of $\mathrm{K}$ silicate minerals, glauconite $\left[\mathrm{K}_{2}(\mathrm{Mg}, \mathrm{Fe})_{2} \mathrm{Al}_{6}\left(\mathrm{Si}_{4} \mathrm{O}_{10}\right)_{3}(\mathrm{OH})_{12}\right]$ and microcline $\left(\mathrm{KAISi}_{3} \mathrm{O}_{8}\right)$. Quartz mineral $\left(\mathrm{Si}_{2} \mathrm{O}\right)$ was also detected in this rock (Fig. 1). After thermal treatment, these crystalline $\mathrm{K}$ minerals collapsed and a new phase, sylvite $(\mathrm{KCl})-\mathrm{a}$ water-soluble $\mathrm{K}$ mineral-was identified (Fig. 1). In addition, quartz mineral remained, being observed as peaks with less intensity at $0.425,0.334$, and $0.245 \mathrm{~nm}$.

After chemical treatment, partial decomposition of crystalline $\mathrm{K}$ minerals and quartz from VR were observed (Fig. 1). Although less intense, peaks were still observed for glauconite $(0.99,0.495,0.33$, and $0.257 \mathrm{~nm})$, microcline $(0.646$, 0.300 , and $0.290 \mathrm{~nm})$ and quartz $(0.425,0.334$, and $0.245 \mathrm{~nm})$. Moreover, peaks associated with arcanite $\left(\mathrm{K}_{2} \mathrm{SO}_{4}\right)$ were also detected (Fig. 1).

\subsection{Greenhouse experiments: growth and potassium uptake by crops}

Verdete rock did not significantly affect the growth or $\mathrm{K}$ uptake by maize and eucalyptus. However, dry matter and $\mathrm{K}$ uptake in grass increased linearly with the rate of $\mathrm{K}$ addition (Fig. 2).
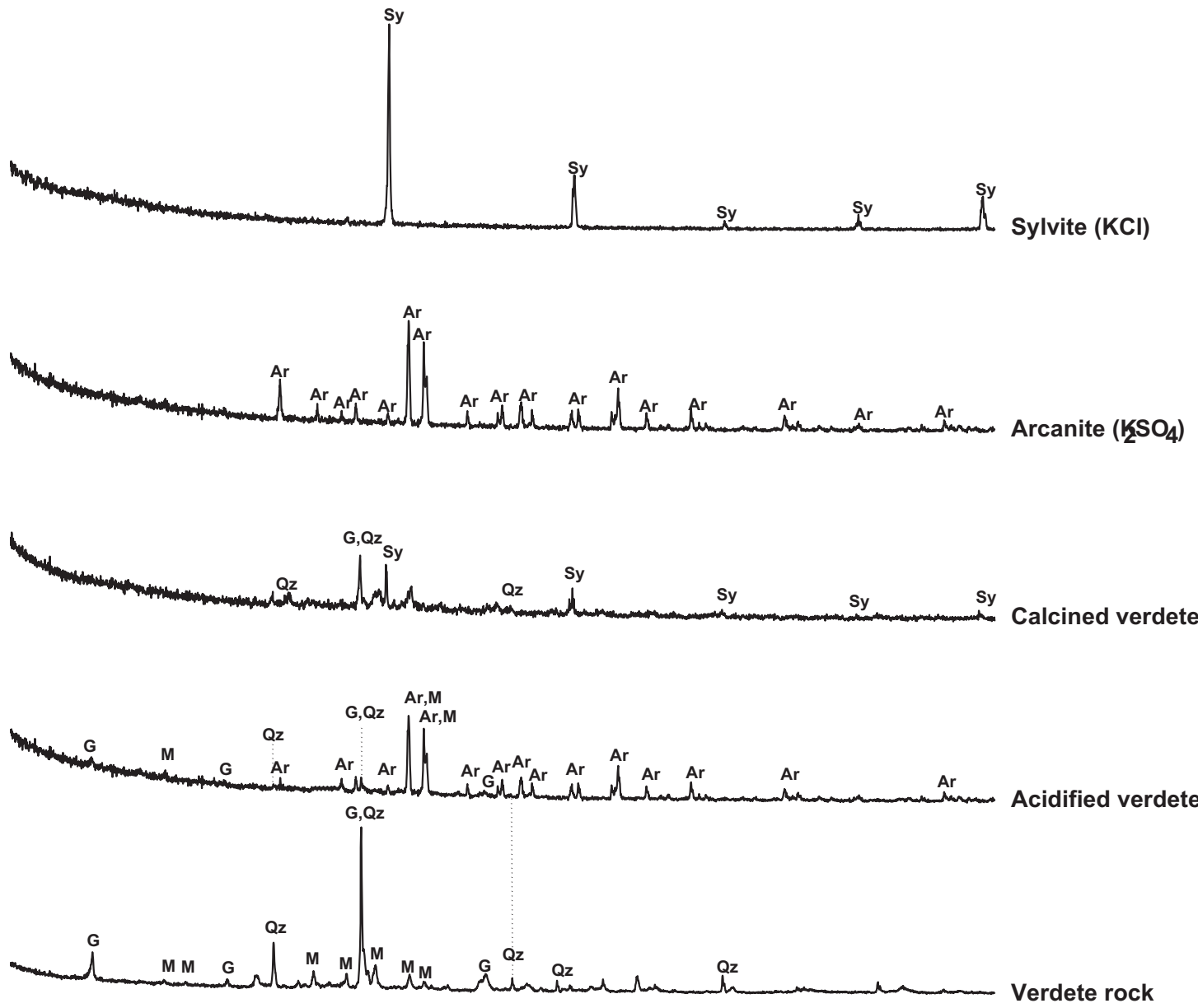

\begin{tabular}{lllccccc}
1 & 1 & 1 & 1 & 1 & 1 \\
\hline 10 & 20 & 30 & 40 & 50 & 60 & 70 & 80 \\
& & & Degree $/ 2 \theta$ &
\end{tabular}

Figure 1: Mineralogical characterization of verdete rock, calcined and acidified verdete, and reference samples of sylvite $(\mathrm{KCl})$ and arcanite $\left(\mathrm{K}_{2} \mathrm{SO}_{4}\right)$. Co $\mathrm{K}_{\alpha 1}$ radiation (1.789 Å). Qz: quartz $\left(\mathrm{SiO}_{2}\right)$; G: glauconite $\left[\mathrm{K}_{2}\left(\mathrm{Mg}, \mathrm{Fe}_{2} \mathrm{Al}_{6}\left(\mathrm{Si}_{4} \mathrm{O}_{10}\right)_{3}(\mathrm{OH})_{12}\right]\right.$; Sy: sylvite $(\mathrm{KCl})$; Ar: arcanite $\left(\mathrm{K}_{2} \mathrm{SO}_{4}\right)$; $\mathrm{M}$ : microcline $\left(\mathrm{KAISi}_{3} \mathrm{O}_{8}\right)$. 
The recovery of $\mathrm{K}$ from VR by grass was $6.1 \%$ of the total amount of $\mathrm{K}$ applied (Table 3).

Comparing the effects of the $\mathrm{CV}, \mathrm{AV}$ and $\mathrm{KCl}$ in terms of $\mathrm{K}$ uptake and dry matter production in maize, we determined that these $\mathrm{K}$ sources promoted equivalent effects. For all fertilizers tested, dry matter production of maize had a quadratic response with rate of $K$ and reached maximum values with 200 , 172 , and $165 \mathrm{mg} \mathrm{dm}^{-3}$ of $\mathrm{K}$, respectively, to $\mathrm{KCl}, \mathrm{CV}$, and $\mathrm{AV}$ fertilizers.
In grass cultivation, the effect of the fertilizers was distinct. No response was observed in dry matter production when $\mathrm{KCl}$ was used as $\mathrm{K}$ source (Fig. 2). However, this fertilizer increased $\mathrm{K}$ uptake linearly as in the other crops. Moreover, VR was more effective in $\mathrm{K}$ uptake by grass cultivation. A quadratic response was observed for $\mathrm{AV}$ in dry matter production of grass, indicating maximum values at $125 \mathrm{mg} \mathrm{dm}^{-3} \mathrm{~K} \mathrm{ac}$ cording to the first derivative of the regression model (Fig. 2).

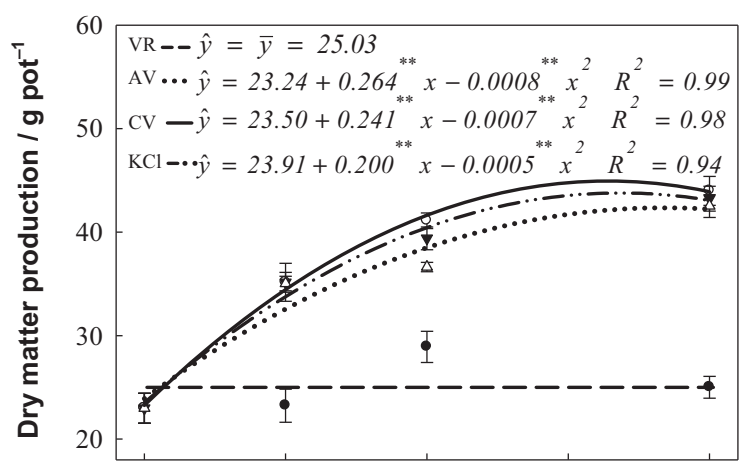

Maize

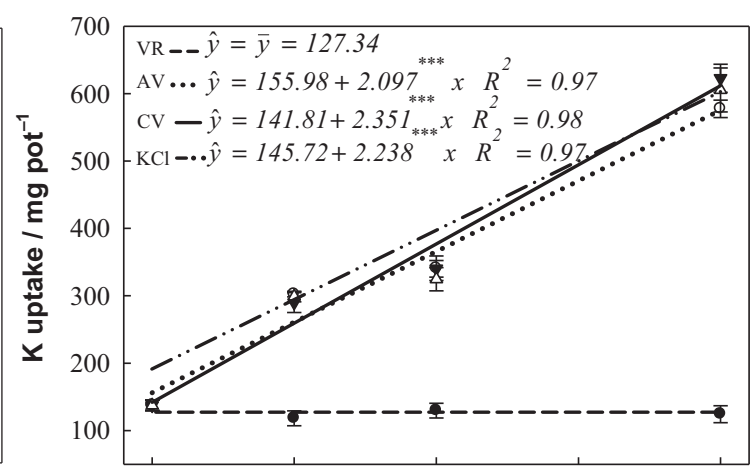

\section{Grass}
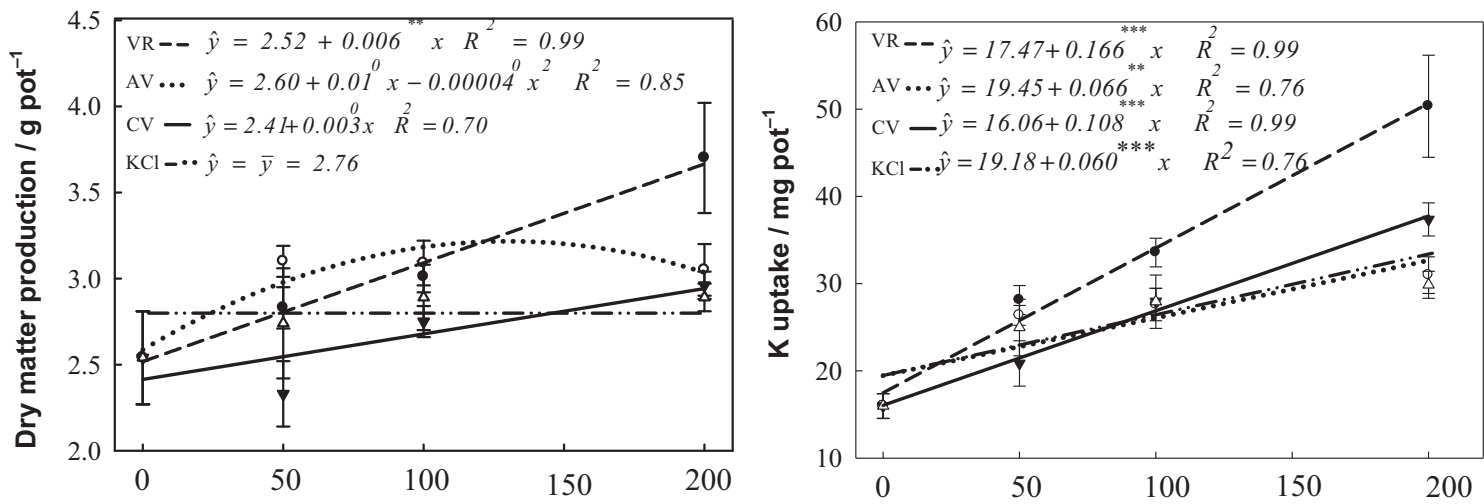

\section{Eucalyptus}

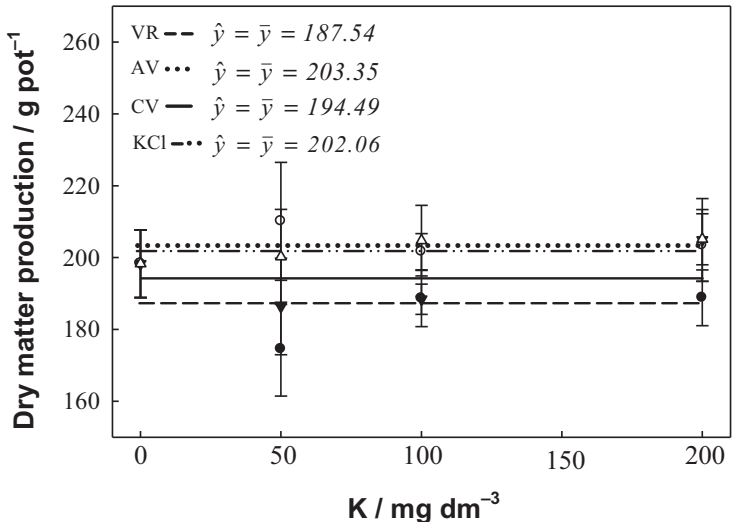

- - - - - Verdete rock $(\mathrm{VR})$

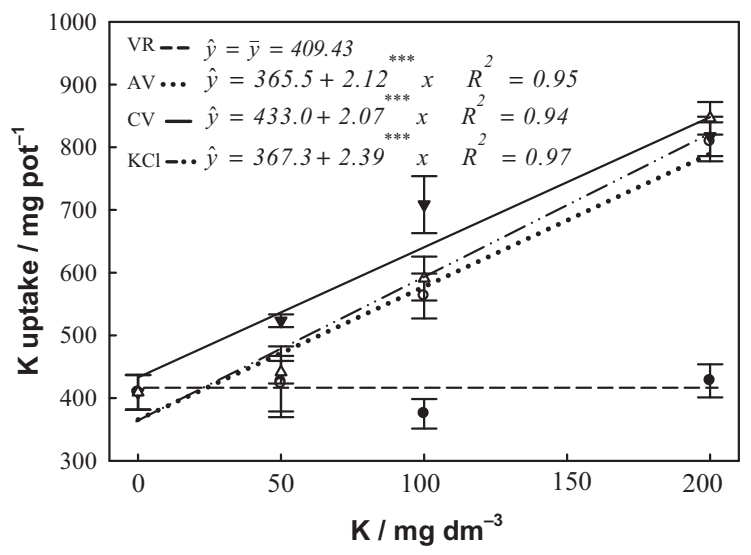

Calcined verdete $(\mathrm{CV}) \quad-\cdots-\cdots-\mathrm{KCl}$

Figure 2: Regression plots that describe the effect of forms and rates of potassium fertilizers on dry matter and $\mathrm{K}$ uptake in maize, grass after maize, and eucalyptus. Vertical bars (I) represent the standard error with 4 replications. 
The recoveries of $\mathrm{K}$ in maize following growth for $45 \mathrm{~d}$ were $70.0,78.3$, and $74.6 \%$ of the total amount of $\mathrm{K}$ applied as either $\mathrm{AV}$ or $\mathrm{CV}$ or $\mathrm{KCl}$, respectively (Table 3 ). In grass, the amount of $\mathrm{K}$ recovered was $2.4,4.0$, and $2.2 \%$ of the applied $\mathrm{K}$ for the $\mathrm{AV}, \mathrm{CV}$, and $\mathrm{KCl}$, respectively (Table 3 ).

Despite the low concentration of $\mathrm{K}$ in soil $\left(17 \mathrm{mg} \mathrm{dm}^{-3}\right)$, the application of $\mathrm{K}$ had no effect on eucalyptus dry matter production until $90 \mathrm{~d}$ after planting (Fig. 2). However, AV, CV and $\mathrm{KCl}$ fertilizers resulted in a linear increase in $\mathrm{K}$ uptake by eucalyptus plants (Fig. 2). Verdete rock did not increase the amount of $\mathrm{K}$ taken up by plants. Potassium recoveries in eucalyptus were $53.0,51.7$, and $59.7 \%$ of the total amount of $\mathrm{K}$ applied as either AV, CV or $\mathrm{KCl}$, respectively (Table 3).

The $\mathrm{K}$ concentration was below the critical value in reference leaves for maize $\left(17.5 \mathrm{~g} \mathrm{~kg}^{-1}\right)$, grass $\left(10.8 \mathrm{~g} \mathrm{~kg}^{-1}\right)$, and eucalyptus $\left(10 \mathrm{~g} \mathrm{~kg}^{-1}\right)$, to which $\mathrm{K}$ was not applied (see Fig. 3). Concentrations of $\mathrm{K}$ in the reference leaves increased linearly with increasing fertilizer $\mathrm{K}$ application, except in the eucalyptus when applied as VR (no response) and as CV (quadratic response) (Fig. 3). Sufficient $\mathrm{K}$ in maize leaves was reached following the application of $82,148,165$, and $155 \mathrm{mg} \mathrm{dm}^{-3} \mathrm{~K}$ as $\mathrm{VR}, \mathrm{AV}$ or $\mathrm{CV}$ and $\mathrm{KCl}$, respectively. For eucalyptus, sufficient $\mathrm{K}$ in leaves was reached with the application of 275 , 125 , and $200 \mathrm{mg} \mathrm{dm}^{-3} \mathrm{~K}$ as AV or CV and $\mathrm{KCl}$, respectively. The reference values for sufficient $K$ in leaves ranges in maize from 17.5 to $22.5 \mathrm{mg} \mathrm{kg}^{-1}$, in grass from 10.8 to $16.5 \mathrm{mg} \mathrm{kg}^{-1}$, and in eucalyptus from 10 to $12 \mathrm{mg} \mathrm{kg}^{-1}$ (Martinez et al., 1999).

\subsection{Potassium in soil}

Soil testing after harvest showed low concentrations of $\mathrm{K}$, even in soils that had the highest doses of $\mathrm{K}$ fertilizers (Fig. 3). Verdete rock and $\mathrm{KCl}$ did not change $\mathrm{K}$ concentrations in soil after maize cultivation, whereas application of treated rock caused a linear increase in $\mathrm{K}$ concentrations. However, the low slopes of the regression equations $(0.030$ and 0.046 ) suggest only a slight increase in soil $\mathrm{K}$. Potassium concentrations in soil reached 17 and $20 \mathrm{mg} \mathrm{dm}^{-3}$ at an application rate of $200 \mathrm{mg} \mathrm{dm}^{-3} \mathrm{~K}$, when $\mathrm{K}$ was applied as $\mathrm{AV}$ and $\mathrm{CV}$, respectively (Fig. 3). After the eucalyptus cultivation, the $\mathrm{K}$ concentration in soil was still lower than that in maize as verified by the intercept and slope of the regression equation (Fig. 3).

\section{Discussion}

\subsection{Mineralogical and chemical characterization}

The high energy at which $\mathrm{K}$ is bonded to the structure of silicates, such as glauconite and microcline, result in its low

Table 3: Estimated values of potassium uptake and their respective recoveries by crops with different forms and rates of potassium fertilizers in a Typic Hapludox with native extractable $\mathrm{K}$ content of $17 \mathrm{mg} \mathrm{dm}^{-3}$ (Mehlich-1).

\begin{tabular}{|c|c|c|c|c|c|c|c|c|c|}
\hline \multirow{3}{*}{ Fertilizer } & \multirow[b]{2}{*}{ K applied } & \multicolumn{4}{|c|}{ K uptake } & \multicolumn{4}{|c|}{$\mathrm{K}$ recovered } \\
\hline & & Maize & Grass & $\begin{array}{l}\text { Maize + } \\
\text { grass }\end{array}$ & Eucalyptus & Maize & Grass & $\begin{array}{l}\text { Maize + } \\
\text { grass }\end{array}$ & Eucalyptus \\
\hline & \multicolumn{5}{|l|}{$/ \mathrm{mg} \mathrm{dm}^{-3}$} & \multicolumn{4}{|c|}{$/ \%$ of amount applied } \\
\hline \multirow{4}{*}{ Verdete rock } & 0 & \multirow{4}{*}{42.4} & 6.5 & 48.9 & \multirow{4}{*}{102.4} & \multirow{4}{*}{-} & \multirow{4}{*}{6.1} & \multirow{4}{*}{6.1} & \multirow{4}{*}{-} \\
\hline & 50 & & 9.5 & 51.9 & & & & & \\
\hline & 100 & & 12.6 & 55.0 & & & & & \\
\hline & 200 & & 18.8 & 61.2 & & & & & \\
\hline \multirow{4}{*}{ Acidified verdete } & 0 & 52.0 & 7.2 & 59.2 & 91.4 & \multirow{4}{*}{70.0} & \multirow{4}{*}{2.4} & \multirow{4}{*}{72.4} & \multirow{4}{*}{53.0} \\
\hline & 50 & 86.9 & 8.4 & 95.4 & 117.9 & & & & \\
\hline & 100 & 121.9 & 9.6 & 131.5 & 144.4 & & & & \\
\hline & 200 & 191.8 & 12.1 & 203.9 & 197.4 & & & & \\
\hline \multirow{4}{*}{ Calcined verdete } & 0 & 47.3 & 5.9 & 53.2 & 108.3 & \multirow{4}{*}{78.3} & \multirow{4}{*}{4.0} & \multirow{4}{*}{82.3} & \multirow{4}{*}{51.7} \\
\hline & 50 & 86.5 & 7.9 & 94.4 & 134.1 & & & & \\
\hline & 100 & 125.6 & 9.9 & 135.6 & 160.0 & & & & \\
\hline & 200 & 204.0 & 13.9 & 218.0 & 211.8 & & & & \\
\hline \multirow{4}{*}{$\mathrm{KCl}$} & 0 & 48.6 & 7.1 & 55.7 & 91.8 & \multirow{4}{*}{74.6} & \multirow{4}{*}{2.2} & \multirow{4}{*}{76.8} & \multirow{4}{*}{59.7} \\
\hline & 50 & 85.9 & 8.2 & 94.1 & 121.7 & & & & \\
\hline & 100 & 123.2 & 9.3 & 132.5 & 151.6 & & & & \\
\hline & 200 & 197.8 & 11.5 & 209.3 & 211.3 & & & & \\
\hline
\end{tabular}


Maize
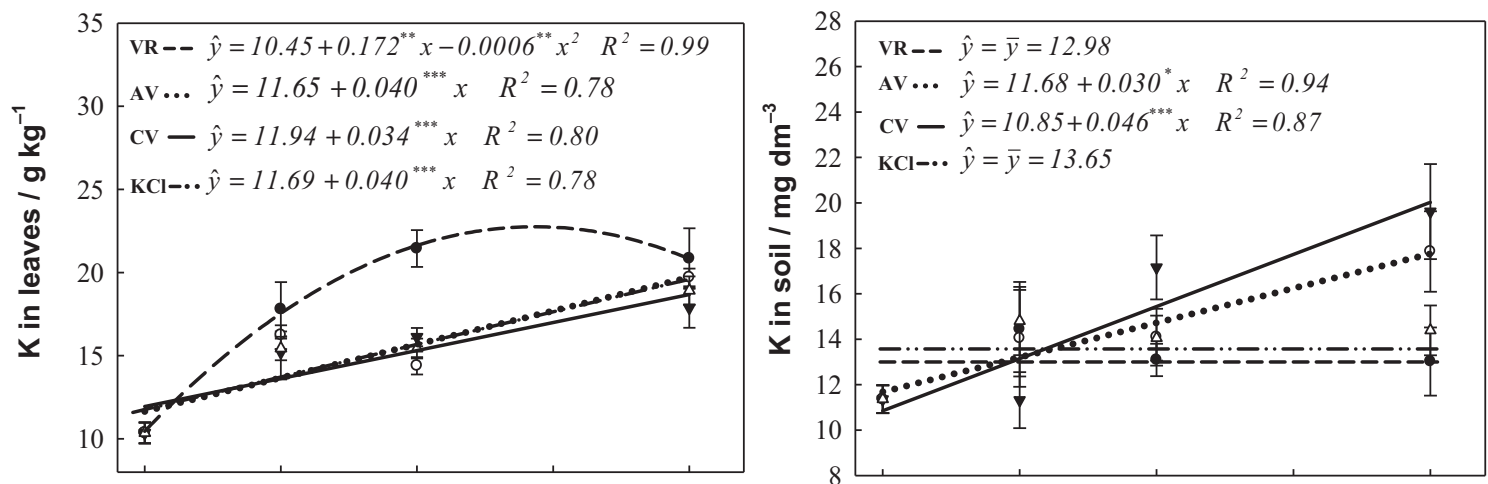

\section{Grass}
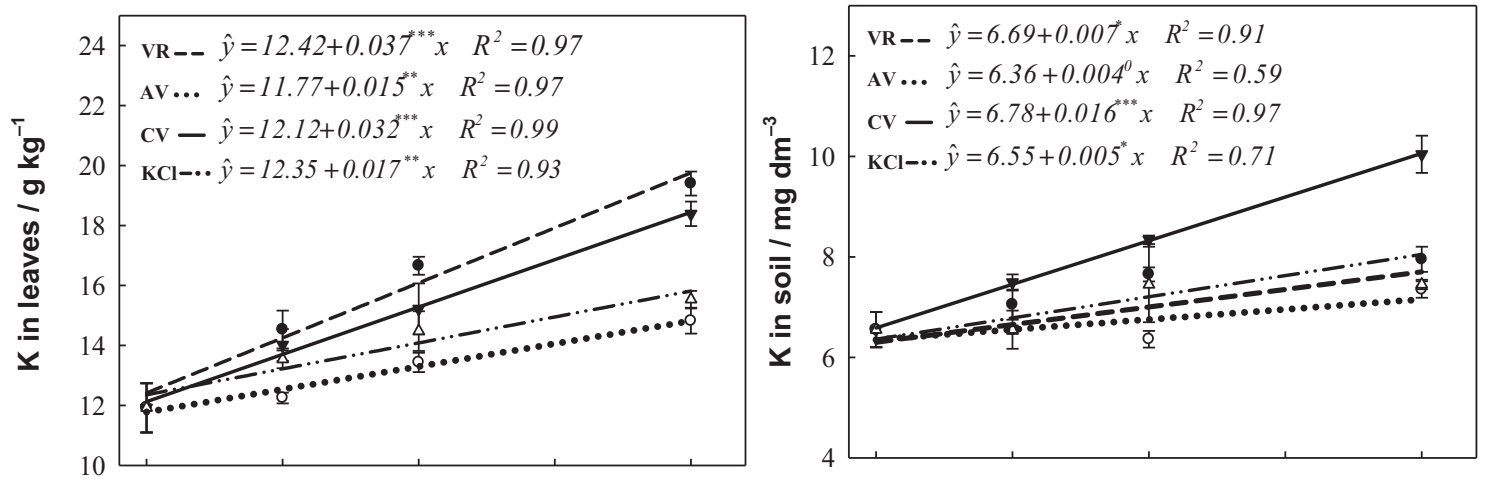

\section{Eucalyptus}
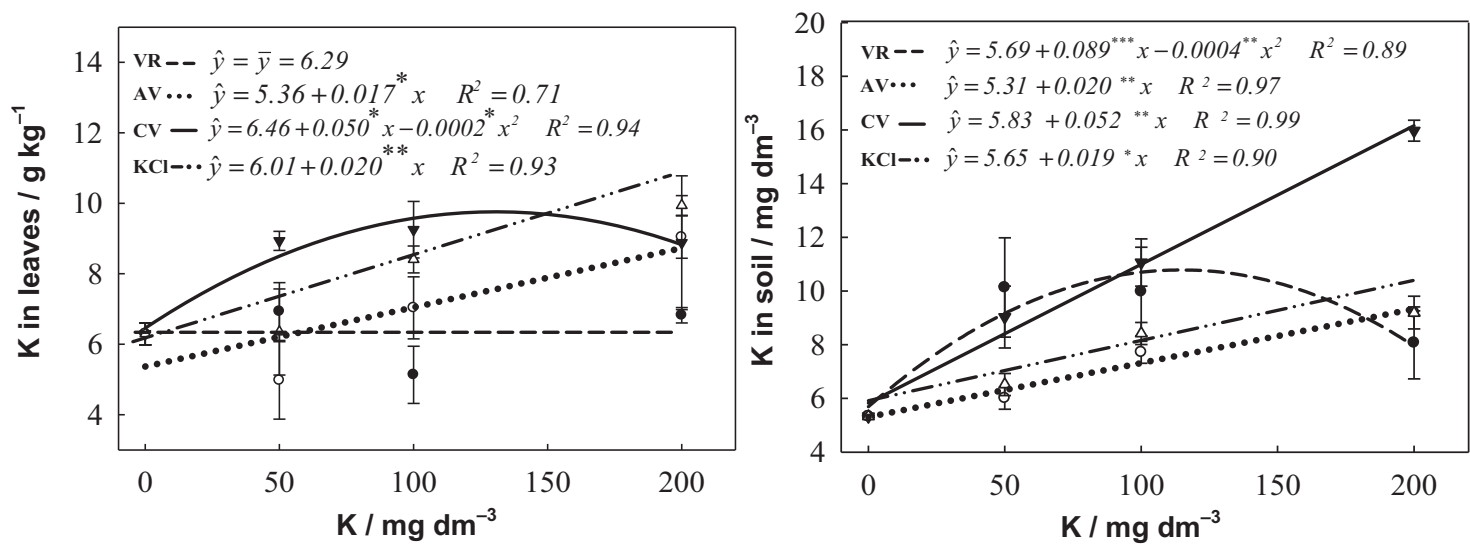

- - - Verdete rock (VR)

Acidified verdete (AV)

- Calcined verdete (CV)

$-\cdots-\cdots-\mathrm{KCl}$

Figure 3: Regression plots that describe the effect of forms and rates of potassium fertilizers on $\mathrm{K}$ concentration in leaves of maize, grass, and eucalyptus and in soil. Vertical bars (I) represent the standard error with 4 replications.

water solubility. This high stability is related to the fact that $\mathrm{K}$ occupies interlayer spaces and is strongly bonded to tetrahedral oxygens in mica-type materials, which have predominantly tetrahedral-sheet charge deficiencies (Marshall, 1964; Kerns and Mankin, 1968).

Both calcination and acidification of the VR were effective at increasing the water and citric acid extractability of $\mathrm{K}$. The extractable $\mathrm{K}$ amounts from AV $[80.6 \%(\mathrm{w} / \mathrm{w})]$ and $\mathrm{CV}$ $[93.7 \%(\mathrm{w} / \mathrm{w})]$ were high compared to that of $\mathrm{KCl}[100 \%(\mathrm{w} / \mathrm{w})]$.
The diffractograms for the $\mathrm{CV}$ and $\mathrm{AV}$ showed that soluble $\mathrm{K}$ minerals such as sylvite $(\mathrm{KCl})$ and arcanite $\left(\mathrm{K}_{2} \mathrm{SO}_{4}\right)$ formed during the collapse of glauconite or microcline structures in the VR. The solubility of sylvite and arcanite in water at $20^{\circ} \mathrm{C}$ are 330 and $111 \mathrm{~g} \mathrm{~L}^{-1}$, respectively (Haynes, 2014).

The potassium minerals from AV were more soluble in water than in citric acid hydrate (Table 2). The low $\mathrm{pH}$ of AIE $(\approx 0)$ combined with citric acid [2\% (w/v)] produced a $\mathrm{pH}$ of approximately 2.0. At this $\mathrm{pH}$, the citric acid remains non-dissociated 
(Bruckenstein and Kolthoff, 1959). This pH contributed to less solubilization of $\mathrm{K}$ from $\mathrm{AV}$ in citric acid extracted samples compared to that in water. Also, the presence of fluorine in the AIE can to promote the silicon dissolution; however this phase is stable in low $\mathrm{pH}$. The isoelectric point of silicon is at a $\mathrm{pH}$ of 1.7 and 3.5 , when its polymerization is optimum (Terry, 1983). This property, associated with the $\mathrm{pH}$ of citric acid solution $(\approx 2.0)$, promotes higher stability for its polymers, and restricts $\mathrm{K}$ release from AV (Terry, 1983). Another possibility to explain the lower $\mathrm{K}$ extraction in citric acid than in water is the formation of potassium hydrogen citrate $(\mathrm{KHC})$ under the conditions of this experiment, at low $\mathrm{pH}$ and presence of citrate and $\mathrm{K}$ in the medium. The dissociation constant of the carboxyl functional groups (present in $\mathrm{KHC}$ ) even in low $\mathrm{pH}$, may to generate negative charges by deprotonation of carboxylic acid permitting adsorption of cations, including $\mathrm{K}$.

To increase the solubility of $\mathrm{K}$ silicate minerals, such as those present in VR (e.g., glauconite and microcline) the presence of fluxing agents is critical (Santos et al., 2015). Calcium chloride has been used as an effective fluxing agent for silicates (Mazumder et al., 1993; Nascimento, 2004; Santos et al., 2015). According to Mazumder et al. (1993), the calcination of glauconite using $\mathrm{CaCl}_{2}$ produces sylvite and calcium oxide as described in Eq. (1):

$\mathrm{CaCl}_{2}+\mathrm{K}_{2} \mathrm{O} \rightarrow 2 \mathrm{KCl}+\mathrm{CaO}$

Chemical stability of the silicates is determined by a combination of structural factors and properties of the metallic cations present (Terry, 1983). The type of acid and the secondary compounds produced during the acid attack have a great influence on the dissolution of $\mathrm{K}$ minerals. The formation of arcanite in the chemical treatment is supported by the high $\mathrm{SO}_{4}^{2-}$ concentration $\left(791 \mathrm{~g} \mathrm{~L}^{-1}\right)$ in the AIE (Table 1).

Acid industrial effluent has a very low $\mathrm{pH}$ and the high concentration of $\mathrm{H}^{+}$is important in order to release $\mathrm{K}$ from VR. Feigenbaum et al. (1981) reported that at a $\mathrm{pH} \leq 3$, the exchange of $\mathrm{K}^{+}$by $\mathrm{H}^{+}$is established in mica structure. Yadav and Sharma (1992) showed that $\mathrm{HCl}$ was a better leaching agent of $\mathrm{K}$ from glauconite in comparison with $\mathrm{H}_{2} \mathrm{SO}_{4}, \mathrm{H}_{3} \mathrm{PO}_{4}$, and $\mathrm{HNO}_{3}$. They were able to solubilize up to $96 \%$ of the total $\mathrm{K}$ from glauconitic sandstones with $\mathrm{HCl} 6 \mathrm{~mol} \mathrm{~L}^{-1}$ at $105^{\circ} \mathrm{C}$ for $180 \mathrm{~min}$. In addition, the fluorine present in the AIE (109 $\mathrm{g} \mathrm{L}^{-1}$ ) was important for dissolving silicon (Hekim and Fogler, 1977).

\subsection{Plant tests}

Our results show that crushed VR could not provide sufficient amounts of $\mathrm{K}$ for maize growth. Furthermore, only $6 \%$ of the amount applied was taken up by grass that was grown for $60 \mathrm{~d}$ following maize. Verdete rock application did not change the concentration of $\mathrm{K}$ in soil after $45 \mathrm{~d}$ of maize cultivation, but an increase in available $\mathrm{K}$ in soil was observed after grass growth $(60 \mathrm{~d})$. These results demonstrate that $\mathrm{K}$ is released very slowly from VR, suggesting that at best it would have long-term residual effect on plant-available $\mathrm{K}$ in soil.
Thermal and chemical treatment of VR produced fertilizers that were similar to $\mathrm{KCl}$ in terms of agronomic performance. These results were expected as these treatments greatly increased the solubility of VR. Potassium solubility is an important agronomical index of fertilizer efficiency since soluble fertilizers are more readily available to plants as shown for maize and eucalyptus cultivation. However, negative effects on plant growth may occur when the dissolution of $\mathrm{KCl}$ is fast, leading to a rapid increase in soil solution $\mathrm{K}$ concentration beyond the optimum range. In this case, a slow-release or a slightly water soluble fertilizer would be advantageous. Supporting these hypotheses, Duarte et al. (2013) demonstrated, comparing the $\mathrm{KCl}$ (high solubility) with a fertilizer produced by thermal treatment of VR mixed with calcium carbonate (low solubility), that losses of $\mathrm{K}$ by leaching were higher in soil profiles when $\mathrm{KCl}$ was the $\mathrm{K}$ source in both clay and sandy soils.

Corn plants growing for $45 \mathrm{~d}$ absorbed more $\mathrm{K}$ than the eucalyptus plants that were grown for $90 \mathrm{~d}$. Our study shows that applying $\mathrm{CV}, \mathrm{K}$ recovered by maize reached a maximum of $78.3 \%$ plus another $4 \%$ recovery by grass after maize cultivation. For eucalyptus plants, maximum recovery was $59.7 \%$ when applied as $\mathrm{KCl}$. A maize crop takes up high amounts of $\mathrm{K}$ to support the initial growth, while eucalyptus plants have a low initial requirement. Besides the distinct ability to acquire $\mathrm{K}$ from the soil, plants have different abilities to utilize $\mathrm{K}$ physiologically (Samal et al., 2010; Hafsi et al., 2011). Our results show that eucalyptus takes up more $\mathrm{K}$ with increasing fertilizers doses, however, no significant effects were observed in terms of dry matter production unlike in maize or grass. The ability of eucalyptus to achieve maximum growth at a lower $\mathrm{K}$ supply may be a consequence of its lower physiological $\mathrm{K}$ requirements than maize to produce biomass.

Soil concentrations of $\mathrm{K}$ after maize cultivation did not increase following the addition of $\mathrm{KCl}$ to soil. This may be due to the rapid plant uptake of $\mathrm{K}$ by maize. However, it was verified with treated VR application. The gradual increases in available $\mathrm{K}$ in soil with treated VR show that such sources are suitable in crops succession, mainly in those areas with potential for this nutrient to be lost through leaching.

In light of the above, soluble $\mathrm{K}$ fertilizers were produced through calcination or acidification of $\mathrm{K}$ silicate rocks. These fertilizers were similar to $\mathrm{KCl}$ in terms of agronomic performance. However, the low $\mathrm{K}$ concentrations make them uncompetitive compared to conventional $\mathrm{K}$ fertilizer $(\mathrm{KCl})$ due to the higher transportation costs for application. However, further price increases of conventional products as observed in 2008/2009 may stimulate investment in developing non-conventional sources for $\mathrm{K}$ fertilizers and make them viable for local use. Moreover, our study shows that an acid industrial waste can be used to increase the rock solubility, thereby producing a low-cost $\mathrm{K}$ fertilizer containing sulfur also.

Many rocks containing $\mathrm{K}$ silicate minerals can be used as alternative raw materials in $\mathrm{K}$ fertilizer production, mainly in those countries with limited soluble $\mathrm{K}$ minerals such as sylvite, arcanite, carnalite, and langbeinite. In addition, studies have shown that other rock types and minerals, such as 
nepheline syenite (Bakken et al., 2000; Nascimento, 2004), biotite (Mohammed et al., 2014), zinnwaldite mica (Madaras et al., 2013), and glauconitic rock (Mazumder et al., 1993; Santos et al., 2015), are viable sources of K.

\section{Conclusions}

Given the need for $\mathrm{K}$ fertilizer production, particularly in regions distant from sources of conventional products, the results presented here demonstrate that thermal and chemical treatments of verdete rock with $\mathrm{CaCl}_{2}$ as fluxing agents and AIE, respectively, modify its mineral composition from insoluble $\mathrm{K}$ minerals to water-soluble $\mathrm{K}$ minerals. Such transformations are important for agronomic performance of these fertilizers when compared to conventional $\mathrm{K}$ sources like $\mathrm{KCl}$. By contrast, untreated verdete rock had no effects on $\mathrm{K}$ supply to maize. However, in the following grass crop, verdete rock promoted an increase in $\mathrm{K}$ absorption, indicating an increase in reactivity over time. Thermal and chemical processes are efficient to increase the plant availability of $\mathrm{K}$ in verdete rock and show promise for the production of K-soluble fertilizers.

\section{Acknowledgement}

The authors are thankful for the financial support received from FAPEMIG (Fundação de Amparo à Pesquisa do Estado de Minas Gerais - APQ-04092-10). We also acknowledge Dr. Casey Doolette (University of Adelaide), and Dr. Richard $W$. Bell (Murdoch University) for critical review of and suggestions regarding this work.

\section{References}

Alcarde, J. (2009): Manual de análise de fertilizantes. FEALQ, Piracicaba, Brazil.

Alecrim, J. D. (1982): Recursos minerais do Estado de Minas Gerais. METAMIG, Belo Horizonte, Brazil.

Bakken, A., Gautneb, H., Sveistrup, T., Myhr, K. (2000): Crushed rocks and mine tailings applied as $\mathrm{K}$ fertilizers on grassland. Nutr. Cycl. Agroecosys. 56, 53-57.

Blum, W. E. H., Herbinger, B., Mentler, A., Ottner, F., Pollak, M., Unger, E., Wenzel, W. (1989): The use of rock powders in agriculture. 1. Chemical and mineralogical composition and suitability of rock powders for fertilization. Z. Pflanz. Bodenkunde. 152, 421-425.

BRASIL (2007): Instrução normativa n. 28, de 23 de fevereiro de 2007. MAPA, Brasilia, Brazil.

BRASIL (2011): Resolução n. 430, de maio de 2011. MAPA, Brasília, Brazil.

Bruckenstein, S., Kolthoff, I. (1959): Treatise on Analytical Chemistry. Wiley, New York, NY, USA.

Coroneos, C., Hinsinger, P., Gilkes, R. (1995): Granite powder as a source of potassium for plants: a glasshouse bioassay comparing two pasture species. Fert. Res. 45, 143-152.

Duarte, I. N., Pereira, H. S., Korndörfer, G. H. (2013): Lixiviação de potássio proveniente do termopotássio. Pesq. Agropec. Trop. 43, 195-200.

Eichler, V. (1983): Disponibilidade do potássio do verdete de Abaeté calcinado com e sem calcário magnesiano, para a cultura do milho em solos de textura média e argilosa. PhD thesis, Universidade Federal de Lavras, Brazil.

Feigenbaum, S., Edelstein, R., Shainberg, I. (1981): Release rate of potassium and structural cations from micas to ion exchangers in dilute solutions. Soil Sci. Soc. Am. J. 45, 501-506.

Hafsi, C., Atia, A., Lakhdar, A., Debez, A., Abdelly, C. (2011): Differential responses in potassium absorption and use efficiencies in the halophytes Catapodium rigidum and Hordeum maritimum to various potassium concentrations in the medium. Plant Prod. Sci. 14, 135-140.

Haynes, W. M. (2014): Handbook of Chemistry and Physics. CRC Press, Boca Raton, FL, USA.

Hekim, Y., Fogler, H. S. (1977): Acidization-VI: On the equilibrium relationships and stoichiometry of reactions in mud acid. Chem. Eng. Sci. 32, 1-9.

Kerns, R., Mankin, C. (1968): Structural charge site influence on the interlayer hydration of expandable three-sheet clay minerals. Clay. Clay Miner. 16, 73-81.

Lima, T. M., Neves, C. A. R. (2012): Sumário Mineral 2012. DNPM, Brasilia, Brazil.

Loureiro, F. L., Nascimento, M., Neumann, R., Rizzo, A. C. (2010): Tecnologias de aplicação de glauconita como fonte de potássio na agricultura: o caso brasileiro e a experiência indiana. Anais do I Congresso Brasileiro de Rochagem 1, 111-119.

Madaras, M., Mayerová, M., Kulhánek, M., Koubová, M., Faltus, M. (2013): Waste silicate minerals as potassium sources: a greenhouse study on spring barley. Arch. Agron. Soil Sci. 59, 671-683.

Marshall, C. E. (1964): Physical Chemistry and Mineralogy of Soils. John Wiley \& Sons, New York, NY, USA.

Martinez, H., Carvalho, J., Souza, R. (1999): Diagnose Foliar, in Ribeiro, A., Guimarães, P., Alvarez, V. (eds.): Recomendações para uso de corretivos e fertilizantes em Minas Gerais. 5a Aproximação. Sociedade Brasileira de Ciência do Solo, Viçosa, Brazil, pp. 143-167.

Mazumder, A., Sharma, T., Rao, T. (1993): Extraction of potassium from glauconitic sandstone by the roast-leach method. Int. J. Miner. Process. 38, 111-123.

Miller, R. O. (1998): Nitric-perchloric acid wet digestion in an open vessel, in Kalra, Y. (ed.): Handbook of Reference Methods for Plant Analysis. CRC Press, Boca Raton, FL, USA, pp. 57-61.

Mohammed, S. M. O., Brandt, K., Gray, N. D., White, M. L., Manning, D. A. C. (2014): Comparison of silicate minerals as sources of potassium for plant nutrition in sandy soil. Eur. J. Soil Sci. 65, 653-662.

Nascimento, M. (2004): Desenvolvimento de método para extração de potássio a partir de feldspato potássico. PhD thesis, Universidade Federal do Rio de Janeiro, Brazil.

Nascimento, M., Loureiro, F. E. L. (2004): Fertilizantes e sustentabilidade: o potássio na agricultura brasileira, fontes e rotas alternativas. Série Estudos e Documentos 61, CETEM/MCT, Rio de Janeiro, Brazil.

Nelson, W. L., Mehlich, A., Winters, E. (1953): The development, evaluation, and use of soil tests for phosphorus availability. Agronomy 4, 153-188.

Ott, $H$. (2012): Fertilizer markets and their interplay with commodity and food prices. JRC Scientific and Policy Reports, European Commission, Seville, Spain.

Ramezanian, A., Dahlin, A. S., Campbell, C. D., Hillier, S., Mannerstedt-Fogelfors, B., Öborn, I. (2013): Addition of a volcanic rockdust to soils has no observable effects on plant yield and nutrient status or on soil microbial activity. Plant Soil. 367, 419-436. 
Samal, D., Kovar, J. L., Steingrobe, B., Sadana, U. S., Bhadoria, P. S., Claassen, N. (2010): Potassium uptake efficiency and dynamics in the rhizosphere of maize (Zea mays L.), wheat (Triticum aestivum L.), and sugar beet (Beta vulgaris L.) evaluated with a mechanistic model. Plant Soil. 332, 105-121.

Santos, W. O., Mattiello, E. M., da Costa, L. M., Abrahão, W. A. P., de Novais, R. F., Cantarutti, R. B. (2015): Thermal and chemical solubilization of verdete for use as potassium fertilizer. Int. J. Miner. Process. 140, 72-78.

Terry, B. (1983): The acid decomposition of silicate minerals part I. Reactivities and modes of dissolution of silicates. Hydrometallurgy 10, 135-150.

Toledo Piza, P. A., Bertolino, L. C., da Silva, A. A. S., Sampaio, J. A., da Luz, A. B. (2011): Verdete da região de Cedro de Abaeté (MG) como fonte alternativa para potássio. Geociências 30, 345-356.
Valarelli, J. V., Novais, R. F., Vaz, M. M. T. (1993): Ardósias" Verdete" de Cedro do Abaeté na Produção de Termofosfato Potássico Fundido e sua Eficiência Agronômica. An. Acad. Bras. Ciências 65, 363-376.

Varadachari, C. (1992): An investigation on the reaction of phosphoric acid with mica at elevated temperatures. Ind. Eng. Chem. Res. 31, 357-364.

Walkley, A., Black, I. A. (1934): An examination of the Degtjareff method for determining soil organic matter, and a proposed modification of the chromic acid titration method. Soil Sci. 37, 29-38.

Yadav, V., Sharma, T. (1992): Leaching of glauconitic sand stone in acid lixiviants. Miner. Eng. 5, 715-720. 